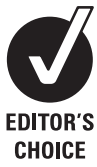

Peninsula College of Medicine and Dentistry, Peninsula Medical School, Universities of Exeter and Plymouth, Truro, UK

Correspondence to:

Dr R Marshall, Peninsula College of Medicine and Dentistry, Knowledge Spa, Royal Cornwall Hospital, Truro, Cornwall, TR1 3HD, UK; robert.marshall@pms. ac.uk

Accepted 3 March 2009

\title{
The death of Hector: pity in Homer, empathy in medical education
}

\author{
R Marshall, A Bleakley
}

\section{ABSTRACT}

Empathy is thought a desirable quality in doctors as a key component of communication skills and professionalism. It is therefore thought desirable to teach it to medical students. Yet empathy is a quality whose essence is difficult to capture but easy to enact. We problematise empathy in an era where empathy has been literalised and instrumentalised, including its measurement. Even if we could agree a universally acceptable definition of empathy, engendering it in the student requires a more subtle approach than seems the case currently.

We therefore examine this modern concept and compare it with others such as pity and compassion, using the medium of Homer's lliad. Two famous scenes from the Iliad elicit pity in the characters and the audience. Pity and compassion are, however, given a complexity within the narrative that often seems lacking in modern ways of conceptualising and teaching empathy.

Every notion of progress is refuted by the existence of the Iliad.

\section{COMMUNICATION: SKILL, OR STYLE FOR LIFE?}

"Communication" is now widely regarded within medical education as a component of medical "professionalism", a learned set of skills and attitudes exhibited in performance, and open to objective measurement or assessment. ${ }^{2}$ Communication includes not only doctor-patient interactions, but working with colleagues (usually in team settings), educating students, and communicating generally with the public. Policy documents typically prescribe how doctors should behave and communicate as professionals, and list the virtues that inform these behaviours. For example, the UK General Medical Council's regularly updated Good medical practice includes "probity" (being honest and trustworthy) amongst its recommendations, suggesting that "probity" and "acting with integrity" are "at the heart of medical professionalism" (GMC 2006, p27). ${ }^{3}$

In a previous article, we argued that, where medical students' learning of communication has been reduced to performance of atomised, instrumental skills (competencies), the complexity of real clinical encounters is lost. ${ }^{4}$ Such encounters are contextually-sensitive and ethical acts. Educationally, they could be grounded more in reflection on life experiences than feedback from actor patients in simulated settings. We argued that communication skills are usually considered ahistorically, as given (transparent and unproblematic) activities. As a result, we suggested a "return to Homer"-as a rich background against which to interrogate contemporary versions of interpersonal communication as part of a doctor's "professionalism". We recognise this historical turn as a rhetorical strategy. In this article, we deepen and extend that argument, once again returning to Homer's Iliad as informing background, but now focusing specifically upon "empathy" and comparing it to pity and compassion as understood in the ancient and modern worlds. Our wider project is to advertise the value of application of classical literature and philosophy to contemporary medical practice and education. Classical literature, in particular, except that about ancient medicine, has been very little examined for its potential to affect the care of patients.

Through a "return to Homer", we problematise the modern notion of "empathy", a pervasive term in medical communication. By questioning what we see as a false division between the cognitive act of empathy and the affective state of compassion and by recovering a more poignant, ancient use of the now abused (and sometimes abusive) term "pity", we have attempted to show how the classics can enrich contemporary medicine. We suggest that knowledge of an epic story such as the Iliad, from the point of view of its tragic content, may provide a "script" that prepares us for a deeper appreciation of the suffering of patients. The latter is an axiom of the literature and medicine school. In problematising "empathy", we have necessarily demanded complexity and ambiguity in an era where many medical educationists concerned with "professionalism" have demanded simplification, clarity, instrumentalism, empiricism and measure. We call for a return of empathy to its grounding in the senses, where empathy can be read metaphorically rather than literally, as a challenge to the reductionist approaches characterised by instrumentalism. Finally, we have argued for a reading of empathy as a verb rather than a noun, so that empathy is context-specific, as act or performance, rather than personality condition.

Homer's use of "pity" in the Iliad offers a striking reminder of the value of critically reviewing the status of words such as "empathy", that have become part of the unexamined fabric of communication skills teaching. We examine scenes in the Iliad which elicit pity in the characters and the audience, offering a mix of the entirely familiar (a soldier saying farewell to his wife and child), and the bizarre (another soldier-hero fighting a river); of gentleness and savagery; of the homely and the foreign. Attempting to project ourselves into the mindset of Homer's audience broadens our understanding of how words and actions are intimately linked. It 
also reminds us that meanings are contingent on the age and peoples that form them.

\section{PITY IN HOMER}

At the end of Book 6 of the Iliad, there occurs a famous scene in which Andromache, the wife of Hector, pleads with him to stay within the city walls and not take the attack to the enemy:

Hector smiled, looking at his son in silence.

But Andromache stood beside him, her tears flowing.

She put her hand in his and called him and spoke to him.

"My lord, your passion will destroy you, and you take no pity

On our little child, nor me, ill-fated, your widow

Soon to be." (Book 6, lines 404-9)

And then at the end of a long speech:

Hector, indeed you are father to me and dear mother

And brother and strong husband.

Come now, take pity and stay here on the rampart

That you may not leave your child an orphan and your wife a widow. (Book 6, lines 429-32)

Hector replies that he would feel shame to avoid the fighting and goes on:

For I know this well in my mind and in my heart, That the day will come when holy Ilium (Troy) will perish, And Priam, and the people of Priam of the strong ash spear. But it is not so much the pain of the Trojans yet to come That troubles me, nor Hecuba herself, nor Priam the king... As the thought of you, when some bronze-armoured Achaean Takes you off in tears, robbing your days of freedom..., But may a mound of earth cover my dead body before I Hear your cries and know they drag you captive. (Book 6, lines $447-65)^{5}$

This is followed by an iconic scene, loved by the ancients, where Hector stretches out his arms to his son but the baby shrinks away from him, scared by the horse's hair plume on his helmet. Hector laughs and removes his helmet, takes his son and invokes:

Zeus, and you other immortals, may this boy, my son,

Be as I am, pre-eminent in war among the Trojans,

Great in strength, as I am, and rule over Troy with strength;

And some day may they say: "This man is better by far than his

father." (Book 6, lines 466-79)

He hands the child back to his mother, who takes him "weeping and smiling at once". Her husband, "noticing this, took pity on her", and says that "no man will kill him unless it is fated, but no man may avoid his fate". And then, in very simple language:

So saying, glorious Hector took his plumed helmet;

And his beloved wife returned home

Turning often to look back. (Book 6, lines 482-96)

And that ends the scene between them. She will not see her husband alive again, though this episode occurs early in the Iliad. We, the audience, know that. We are already familiar with the story, and that is the point. Experienced doctors make good clinical judgements with ease because they access stored "scripts" from previous, similar, encounters. This principle stands for communication exchanges also. But scripts are also at hand in literature, and perhaps the most common argument for the value of studying literature for practising medicine is that stories prepare you for patients' plots and characters; and genres, such as tragedy, offer archetypal scripts. ${ }^{6}$ Exposed to such scripts as the parting of Hector and Andromache, pity is, as it were, hard-wired.

Homer's audience, indeed any later Greek or Roman audience, would have known the Troy story intimately; known therefore that it is scripted that Hector will die at the hands of Achilles, and that Troy will fall. For them, and for us, the poignancy of the scene above is deepened by knowing that Hector's words accurately foretell the fate of Andromache and that the baby will be hurled from the walls of Troy. Such foreknowledge by the audience is characteristic of Greek tragedy (of which Homer was regarded as the father). Generally speaking, we prefer not to know how things will turn out. The pity of the ancient audience is greater because they know what will happen to Hector and his family-the arc of the tragedy. It is a feeling familiar to those caring for patients-pity for someone of whose fate we have an understanding broader than, or certainly different from, theirs, given by the work doctors do. Entering the mind of the other, which we take to be an essential characteristic of empathy, is, in such a case, a valuable but different process, because the other, the patient, does not always know his or her fate.

\section{COMMUNICATION, VIRTUE, VIRTUOSITY}

Consider the adaptability in communication that a communitybased practitioner must develop: in multicultural settings, with children, with the elderly and confused, and with persons across a spectrum of disabilities, including mental health issues. This same doctor will also engage with the "autonomous patient" who properly rejects paternalism, with patients' advocates including family members, and with the savvy internetinformed patient. How shall we best prepare medical students for such intense relationships? It is important that we do this well, as there is a growing body of evidence demonstrating that the quality of the relationship between doctor and patient has an effect on health outcomes beyond, simply, patient satisfaction. ${ }^{8}$

While communication skills are included in learning outcomes across the spectrum of medical curricula globally, and are at the heart of recommendations concerning good medical practice, just how to best teach such skills is debated. ${ }^{39}$ There is an emerging trend towards use of "safe" simulated settings with both actor patients and expert patients, involving videotaped encounters and direct feedback in custom-built clinical skills laboratories or communication suites. Proponents argue that this offers both "standardisation" of experience and possibility of standardised assessment..$^{10}$ Assessment is usually through a station of an objective structured clinical examination. In such undergraduate assessment contexts, typically a set of skills, such as "shows empathy", "maintains eye contact", "communicates information clearly and precisely" are atomised as "competencies", serve as learning outcomes, and offer assessment criteria. This instrumental approach is now seamless with postgraduate education. For example, the UK General Medical Council's The new doctor specifically lists competencies to be achieved for a Foundation (Junior) doctor to progress to registration, including demonstrating "empathy and the ability to form constructive therapeutic relationships with patients" (GMC 2007, p86). ${ }^{9}$

However, "empathy" is a problematic term. As Veloski and Hojat" warn, "the theoretical investigation of physician empathy has been hampered by ambiguity in its conceptualisation and definition", where "there is no agreed-upon definition 
of the term". Worse, empathy may be an operational term for a psychological state that "may not even exist". ${ }^{11}$ Empathy then becomes not something to define but a metaphor to help us understand a mental activity. Indeed, the key contemporary text on empathy in medicine, Empathy and the practice of medicine: beyond pills and the scalpel, published in 1993, is, paradoxically, replete with the authors' uses of metaphors to describe empathy in a collection that is otherwise characterised by the desire to represent empathy as an empirical phenomenon. ${ }^{12}$ Metaphors of transportation, site and resonance are common, and commonly occur together, describing placing oneself in the lived experience of the patient's illness, and entering the perceptual world of the other, as cognitive events of understanding and insight, rather than compassion. In a book-length empathic treatment of "sympathy", Lauren Wispé discloses the core metaphor for empathy as that of travel, or crossing over. ${ }^{13}$ This raises questions concerning the motives for that travel, from anthropological study, to the morbid curiosity of the tourist, to the desire for conquest and control of the imperialist or colonist.

Such (in our view, necessary) conceptual ambiguity places us in the same position as the circular operational definitions of ambiguous psychological notions such as "intelligence" - that "intelligence is what intelligence tests measure". Empathy may be what empathy scales measure, or is a construct, a useful heuristic, rather than a tangible state of being. Yet, we undeniably feel in the presence of suffering, and here, we argue that a better descriptor for this feeling is "pity" as described by Homer. Substituting pity for empathy is not merely a semantic sleight of hand.

The dictionary definitions of "empathy" and "pity" reinforce our argument that empathy is a modern, operational term, grounded in technical-rational thinking; where pity is an ancient term grounded in the senses. The shorter Oxford English dictionary defines empathy as: "The power of projecting one's personality into, and so fully understanding, the object of contemplation". In contrast, pity is defined as "A feeling of tenderness aroused by the suffering or misfortune of another, and prompting a desire for its relief". The first definition implies mastery, the second, a contemplation and appropriate action, importantly qualified by the descriptor "tenderness". This is a more feminine response of discrimination-hence our claim that this is grounded in the senses, rather than the instrumental.

You would think that the dictionary definition of pity is hard to beat, but the word has been corrupted in modern usage, as a kind of sneering. The novelist Graham Greene starkly captures this view: "Pity is cruel. Pity destroys. Love isn't safe when pity's prowling round." 14 And Michael LaCombe, writing in the persona of a senior devil to a junior colleague, recommends using pity to pervert empathy: "permit them to see their patients as simpering fools, helpless wrecks of humanity with whom they could never identify. Let this pity grow, spread like a cancer within them, and you need not worry". ${ }^{15}$ Such an understanding of pity is idiosyncratic. It requires a distancing from the object and a feeling of superiority that, we suspect, most would not think was implicit in the term. Definitions matter. Or perhaps this is a matter of understanding and experience rather than definition.

The roots of empathy and compassion appear superficially similar: -pathy and -passion derive, one Greek, the other Latin, from words to do with suffering. Their difference lies in their prefixes-suffering "in" ("em") or "with" ("com"). In fact, the Latin word patior, from which "passion" derives, had a meaning largely confined to suffering or tolerating unpleasant experiences, whereas pathos was a much more neutral word meaning experiences both good and bad. Chambers dictionary subconsciously reflects this ambiguity by translating the "pathy" of empathy as "feeling", and of sympathy as "suffering". The word sympathy existed in classical Greek times with a meaning very similar to today's; empathy, in classical Greece, meant a state of emotional engagement, positive or negative, (the opposite of apathy). "Pity" derives from the same word as "piety", the Latin pietas. In old and middle English, the two senses were intermingled, only separating in the $16^{\text {th }}$ century, when both words took on negative meanings-as a kind of knowing superiority.

Paradoxically, when empathy entered modernist thinking, it was wholly grounded in aesthetics, but has since lost this foothold. Although Jodi Halpern finds echoes of the term in Hippocrates, it is a $20^{\text {th }}$ century invention, formally coined by the German psychologist Titchener in 1909 as a translation of the German einfühlung-literally meaning "aesthetic sympathy". ${ }^{16}$ Indeed, Titchener's description only provides further ambiguity, where he says of empathising with another's expressions or qualities, such as pride, that he "feels them in the mind's muscle". ${ }^{13}$ The metaphor is again one of movement, of crossing over, of a paradoxical "at-a-distance" proprioception, but now we are in the body of the mind, an unfamiliar territory for contemporary cognitive models of empathy.

The German philosopher Theodore Lipps (1851-1914), who had a formative influence on Freud's model of the unconscious, used einfühlung as early as 1903, originally in aesthetics, to describe a process of the observer "entering into" a work of art, and it is only later that such language was used by him to describe entering into the mind of a person. Importantly, in these early formulations, the passions are clearly engaged, and this differs greatly from contemporary definitions of empathy as the cognitive or knowing partner to affective "compassion". Our conclusion is that there is not only conceptual confusion concerning "empathy", but that the word as currently defined ignores its derivation, in that "pathos", in its original Greek meaning, is a state of emotional engagement.

As the GMC emphasises virtues such as probity and integrity, we should examine virtue, as did the ancient Greeks. (We follow the well-trodden path that there is a direct link between ancient Greek and current Western thinking. $)^{17}$ Discussions of virtue thread through Plato, particularly Meno, Protagoras, Republic and Laws. Meno, a dialogue between Socrates and a young aristocrat (Meno), opens with Meno's question to Socrates: "is virtue something that can be taught? Or does it come by practice? Or is it neither teaching nor practice that gives it to a man but natural aptitude or something else?" Socrates' rhetorical strategy is to not answer the question, but to direct attention to the key prior question: what is virtue? In answer to this, Socrates says: "The fact is that far from knowing whether it can be taught, I have no idea what virtue itself is" (Plato 1956, p115). ${ }^{18}$

Over 2400 years later, Louise Arnold and David Stern graphically model medical "professionalism" as a classical Greek temple, where the supporting base (as three steps) is composed of "clinical competence" (knowledge of medicine), "communication skills", and "ethical and legal understanding". ${ }^{19}$ The roof is "professionalism" and the pillars supporting the roof are four virtues: "excellence", "humanism", "accountability" and "altruism". The authors explicitly equate professionalism with "virtue". "Excellence", currently a buzzword in medical education policy documents, is characterised by "a commitment to exceed ordinary standards". Here, a return to 
classical Greece will help us to further define "excellence", and also sharpen our understanding of "virtue". This, in turn, will lead to a better understanding, and appreciation, of "empathy".

In describing the relationship between rhetoric and athletics in ancient Greece, Debra Hawhee describes a tradition of naming specific virtues, such as courage, but also of describing an overall "virtuosity" (aretē).$^{20}$ Hawhee describes Greek athletic competition as a form of "rhetorical practice and pedagogy" (Hawhee 2004, p17) ${ }^{20}$ in which competitors persuaded, or won over, the audience through their bodily prowess or virtuosity. In early Greek athletics, winners were judged by their ability to enter the field of play (agōn) as a warrior enters the battle, showing the virtues of courage, honourable engagement and physical prowess. However, as athletic contests matured, virtuosity was judged as excellent where it explicitly avoided moralising or piety. This subtle shift framed virtuosity as a highly focused or concentrated activity combining physical prowess (skill) with a wisdom of the body (mêtis) that is best translated as "adaptability", and an art of timing or exploiting opportunity (kairos). This combination goes well beyond mere competence, turning sport into performance art. In the field of play that is the agōn of communication in medical practice, excellence might better be termed virtuosity, where virtuosity is a combination of skill (in reading, and responding to, cues), adaptability and the art of timing.

Let us explore this a little further with emphasis upon empathy. While technical virtuosity - for example as surgeon, diagnostician, psychiatrist-is easy to grasp, how might we frame virtuosity in the non-technical realms, such as communication and its subset of empathy? Arnold and Stern describe empathy as a subset of "humanism"- - one of their four pillars of virtue-along with respect, compassion, honour and integrity. ${ }^{19}$ Further, these virtues must be enacted (or performed) for them to have any meaning, and this enactment is embodied in communication that is clinically informed and ethical. These authors distinguish empathy from compassion, where empathy is defined as a cognitive "ability to understand another person's perspectives, inner experiences, and feelings without intensive emotional involvement", plus "the capacity to communicate that understanding". Compassion, in contrast, refers to the affective dimension of being "moved by the suffering or distress of another and by the desire to relieve it". As we shall see, when Homer describes what we might now call the skilful employment of empathy, he uses the term "pity", which artfully collapses the modern technical (and arbitrary) distinction between cognitive and affective components.

Our shift from the virtue of the communicator to virtuosity in communication serves an important function-it links us back to classical thought in two senses. First, in Homeric Greek language (and then thinking), there is no sense of personal agency as intention. Medical students come with the modernist cultural baggage of "introspection", "autonomy" and "selfregulation", descriptors that would have had no meaning in Homeric Greek. Empathy is considered as something that comes from within oneself and is projected onto another, as the dictionary definition suggests. In Homeric Greek, there is no "I" who is "empathic". Rather, pity is embodied in an action, or is a verb. Ruth Padel, in discussing images of suffering in ancient Greek literature, does what medical educators now encourageshe shows that a value or a virtue can only be understood in terms of a performance. ${ }^{21}{ }^{22}$ It is not what the medical student thinks that matters, but how she acts.

In Homeric Greek, many verbs, often those describing what goes on in the head, do not exist in the active form; there is no first person active voice ("I understand you"). Rather, these notions are expressed as a "middle voice" verb, which is "very close to passive, what is done to you by an outside agent" (Padel 1995, p23). ${ }^{22}$ Not "I am disappointed", but "disappointment is upon me", and this is known in the form of the resultant activity-disappointment as performance. "Wishing" and "fearing", for example, do not exist in the active form. They look passive in the Greek but have the connotation of agency moving out from oneself and coming back. If empathy, recast as pity, is considered as a verb rather than a personality trait, it is enlightening to consider it in this middle voice. This unhooks us from "character training" in medicine, and undue reliance upon role modelling. Rather, we are now interested in how medical students act with patients. Returning to Homer makes us think of "patient centredness" as a verb.

Second, while we have warned against cultivation of personality type in favour of consistently observable activities of patient centredness, a return to classical thought also helps us to reframe the virtuous personality in terms of identity. Let us return to the conceptual model of professionalism proposed by Arnold and Stern. ${ }^{19}$ As described above, a supporting pillar, or virtue, central to professional behaviour is humanism, which includes empathy and compassion. Humanism is defined as "a sincere concern for and interest in humanity" (Padel 1995, p22), ${ }^{22}$ without which, how could doctors treat a variety of patients with concern? We will not pursue here the difficulties presented by that weasel-word "sincere", connected as it is with probity or honesty. Rather, we are interested in the implications of "humanism" and its relationship to identity.

In an effort to provide an alternative to the humanistic tradition's way of thinking about "selfhood" and identity, Michel Foucault made a close study of late Greek and early Roman texts that describe a "care of the self". ${ }^{23}$ These texts do not address a core self that must then realise its potential but show how an ethical self can be developed, constructed or produced. In the same way that athletes can attain virtuosity through practice and artful engagement, so persons can shape themselves aesthetically, or "form" character. Such a background provides a new reading of medical education-not just as a technical training, but as an aesthetic self-forming, to shape a professional identity. Hawhee equates this process with phusiopoiesis (Hawhee 2004, p93). ${ }^{20}$ First described by the preSocratic philosopher Democritus, phusiopoiesis is the "creation of a person's nature" (p93, our emphasis) ${ }^{20}$ grounded in poetics or aesthetics, not in instrumental "skill".

Foucault discusses texts by Philo of Alexandria (20 BCE-50 CE) and Epictetus (c.55-135) that suggest those interested in care of the soul, as well as care of the body, could form a "clinic" where you learn collectively how to do philosophy (Foucault 2005, pp98-9). ${ }^{23}$ We can readily translate this into contemporary medical education, where aspiring doctors learn both how to treat the body and how to set up the circumstances that will offer a healing or therapeutic relationship with patients. Importantly, at the same time, the medical student is doing work on identity, or forming a style of life.

In Foucault's reading, Epictetus (pp339-40) ${ }^{23}$ provides far more sophisticated advice on speaking and listening than most contemporary texts on the medical encounter. For example, Epictetus warns about being captivated by the speaker and not listening-through to what is underneath the surface talk. This recognises that talk is acting rhetorically, and certain persuasive elements must be recognised and challenged. Listening is also charged rhetorically. We can listen in various ways-hearing what we want to hear (rhetorical listening), missing the point 
(not listening well), or listening well (offering benefit both to speaker and listener), including knowing when to be silent. Speaking and listening are not instrumental but an art, requiring discrimination and diligent practice.

\section{A RETURN TO PITY}

Hector's foreboding of the fall of Troy is correct. But Homer's Iliad ends before the fall of Troy, with Hector's death. He is killed by Achilles in revenge for Hector's slaying of Patroclus, the beloved friend of Achilles. Achilles defiles the body by dragging it around the walls of Troy and denying it burial. The climactic ending is the secret visit of Priam, the Trojan king, to the Greek camp to beg for the return of his son's body for burial. He starts by reminding Achilles of Achilles' own father, Peleus, and comparing Peleus' fate with his, Priam's, own:

Reverence the gods, Achilles, and take pity on me

Remembering your father, yet I am still more pitiful.

I have endured what no man else on earth has endured before.

I have brought to my lips the hand of the man who killed my

son. (Book 24, lines 486-506)

The Greek word eleos, used in this dialogue, can mean both "pity" and "mercy". Kyrie eleison means "Lord, have mercy on us" but also "Lord, pity us". In examining how wars are memorialised, Tatum hesitates between the use of pity or compassion to describe the feeling of Achilles for the old man. ${ }^{24}$ He appeals to "modern usage" to draw a distinction between the two words that we suspect does not exist for most contemporaries.

Since the death of Patroclus, Achilles has behaved like a savage, slaughtering the enemy in vast numbers even when they are disarmed and beg for mercy; he has sacrificed Trojan princes at the funeral pyre of Patroclus. Since his quarrel with Agamemnon at the beginning of the Iliad, Achilles' refusal to take part in the war has been morally suspect. With his later actions, he moved beyond the pale of acceptable morality. The above scene with Priam restores his humanity. He takes Priam by the hand and, knowing that his own death will come soon, tells Priam that suffering is the lot of man, that Zeus keeps two jars at his feet, evils in one and blessings in the other, which he distributes randomly to humans. In this speech, says Macleod, "there is endurance and sadness, but no bitterness, no railing or cringing". ${ }^{25}$ And, "This is also the fullest and deepest expression in words of Achilles' pity for the suppliant; for pity, as Homer and the Greeks represent it, is a shared human weakness. And it is pity which is at the heart of Homer's conception of poetry." The body is restored and receives burial.

Such was the spirit of compassion that infused this last book of the Iliad, that some late commentators argued it could not belong to the original version. One powerful argument for its integrity is the apparently unconnected scene between Hector and Andromache described above. It contrasts Hector, a man with a wife and child, the main defender of his city, who undertakes a task to which he feels ethically bound, with the solitary, selfish Achilles, driven only by wrath and a desire for revenge. 2526

There are also deliberate echoes in this scene that take us back to the very beginning of the Iliad, when Agamemnon harshly rebuffs the pleas of another father, and initiates events that lead to the deaths of Patroclus and Hector. The epic turns a great circle until a quarrel that started in Book 1 with a suppliant to a king, is resolved with a king who is now the suppliant. Both protagonists at the beginning (Agamemnon and Chryses) will survive the war; those at the end (Achilles and Priam) will die. Achilles is a better man than Agamemnon because he can regain his humanity and do what is right. The body is restored to Priam, who takes it back to Troy for cremation and burial. The pity of the audience is elicited for a final time by the lamentations of the three women most important to Hector during life-his wife Andomache, his mother Hecuba and Helen. It is striking that almost the last words of the epic are left to Helen. In a sense, she had nothing to do with him (as relative, wife or lover), but she is ultimately responsible for his death, because she left her husband to elope with Paris and brought the Greeks in pursuit to Troy. Hector and Priam are the only two of the city's inhabitants who have treated her with kindness and without reproach since she left her home. It leaves the epic on a note of ambiguity. We are left looking backwards and forwards, to the wrongs done in the past and the many deaths to come in the future. Helen, the cause of the war, is one of the few to survive it.

\section{CONCLUSIONS: EMPATHY ANCIENT AND MODERN}

Examination of the Iliad, a foundation stone of Western thought, reassures us with scenes like those recounted above, with which we can identify easily. Yet we should learn from Homer that such identification is facile. For example, it is commonly assumed that women are more "empathic" than men, and Hojat and colleagues confirm this as a significant difference in scores between male and female medical students. ${ }^{27}{ }^{28}$ Yet Homer elaborates his view of pity and compassion largely through male characters. It can be argued that the sharp contrast between their heroic aggression and savageness and their familial tenderness makes the quality of pity more subtle, evanescent and complex. We have already argued that listeners to Homer's stories in the oral tradition may have been sensitised to pity, as the story unfolds in a characteristic manner. Yet Hojat and colleagues, in a further chapter in their extensive research programme on empathy in medicine, suggest that medical students are de-sensitised, or lose empathy, as they move through medical school (yet see more patients). ${ }^{29}$ This is often explained as a necessary development of defence against the sheer volume of distressing circumstances that the doctor will meet. But these studies come with a health warning - the data are based on measurement of "empathy" —an "object" that may be constructed by its measurement.

If we take the core of the meaning of empathy as engaging with, and understanding, the mind of another, it may seem unsurprising that there was no word to describe this over two millennia ago. More importantly, the notion of entering the mind of another would have been incomprehensible to ancient Greece-at least for humans. ${ }^{21} 22$ The Gods, or natural forces, may do this through dreams, and do so in the Iliad. ${ }^{i}$ We should pay more attention to the metaphors we use in describing empathy. What do we mean by "entering" the mind of another, or "resonating with" it? We automatically locate the mind within the brain. Where Homer located it would have depended on what precisely was being described. Thoughts were located in the lungs (phrenes), the diaphragm (thumos), or the liver (thymos) and did not arise there but entered these organs as responses to events; consciousness was more nebulous - an airy substance located in blood or breath. ${ }^{21}$ Emotions were more complex still, located in the chest, heart, liver, or breath. ${ }^{30}$ But is this any cruder or more primitive than locating "mind" in brain? The complexities of language, of course, will subvert such

${ }^{\mathrm{i}}$ For example lliad Book 2, lines 1-75. ${ }^{5}$ 
locations through metaphor, for example Titchener's embodiment of mind in locating empathy in the "mind's muscle"-a way of saying that we are moved by things.

Recall two events mentioned earlier-the sacrifice of the princes, and throwing Hector's baby son from the walls of Troy (the latter episode not in the Iliad but known to the audience and haunting the scene with Andromache described above). The Iliad is full of savagery-the killing of enemies by painful and grotesque means; boasting over the corpse; refusing to spare the life of a helpless foe. It is a small step to label those who do savage deeds as "savages", or "primitives". Yet our own killing is savage, but done by others, usually at a distance, usually unseen. In the film Troy, Hollywood rewrites classical mythology to avoid unpleasantness and sweeten a pill too bitter for modern audiences. In the scene between Hector and Andromache, Hector shows her a secret way out of Troy and, at the end of the film we see her and the baby escaping. Hollywood does not want to know about its heroines led off to concubinage, and babies hurled from city walls. Yet such events still happen. Even if empathy could be taught, would it be fair to our students? Would not classes in narcissism and selfinterest be of greater benefit? There has been no evolution, no progress in our moral sensitivity. Pity, sympathy, empathy and compassion have been examined formally in medical education for only half a century. ${ }^{31}$ The stories of Greece and Rome resonate with us still and can inform our ethical practice.

Acknowledgements: We would like to thank our students for keeping us on our toes.

Competing interests: None.

\section{REFERENCES}

1. Calasso R. The marriage of Cadmus and Harmony. London: Vintage, 1994:103.

2. Stern DT, ed. Measuring medical professionalism. Oxford: Oxford University Press, 2006.

3. General Medical Council. Good medical practice. GMC UK, 2006

4. Marshall RJ, Bleakley A. Putting it bluntly: communication skills in the lliad. Med Humanit 2008:34:30-4.

5. Monro DB, Allen TW, eds. The Iliad. Oxford: Oxford University Press, 1920, $3^{\text {rd }}$ edn. (All translations in this paper are by RJM)

6. Kleinman A. The illness narratives: suffering, healing and the human condition. New York: Basic Books Inc., 1988.
7. Coulter A. The autonomous patient: ending paternalism in medical care. London: The Stationery Office, 2002.

8. Roter DL, Hall JA. Doctors talking with patients/patients talking with doctors: improving communication in medical visits. Westport, CT: Praeger, $2^{\text {nd }}$ edn, 2006.

9. General Medical Council. The new doctor 2007. GMC UK, 2007.

10. Klamen D, Williams R. Using standardized clinical encounters to assess physician communication. In: Stern DT, ed. Measuring medical professionalism. Oxford: Oxford University Press, 2006:53-74.

11. Veloski J, Hojat M. Measuring specific elements of professionalism: empathy, teamwork, and lifelong learning. In: Stern DT, ed. Measuring medical professionalism. Oxford: Oxford University Press, 2006:117-46.

12. Spiro HM, McCrea MG, Curnen EP, et el, eds. Empathy and the practice of medicine beyond pills and the scalpel. New Haven, CT: Yale University Press, 1993

13. Wispé L. The psychology of sympathy. Kluwer/Plenum, 1991:78

14. Greene G. The ministry of fear: an entertainment. Harmondsworth: Penguin Books, 1993.

15. LaCombe MA. Letters of intent. In: Spiro HM, McCrea MG, Curnen EP, et al, eds Empathy and the practice of medicine: beyond pills and the scalpel. New Haven, CT: Yale University Press, 1993:54-66.

16. Halpern J. From detached concern to empathy: humanizing medical practice. Oxford: Oxford University Press, 2001.

17. Fredrick D. Introduction: invisible Rome. In: Fredrick D, ed. The Roman gaze: vision, power, and the body. Baltimore, Maryland: The Johns Hopkins University Press, 2002:1-30.

18. Plato. Meno trs. WKC Guthrie. In: Protagoras and Meno. Harmondsworth: Penguin Books, 1956.

19. Arnold L, Stern DT. What is medical professionalism? In: Stern DT, ed. Measuring medical professionalism. Oxford: Oxford University Press, 2006:15-37.

20. Hawhee D. Bodily arts: rhetoric and athletics in ancient Greece. Austin, TX: University of Texas Press, 2004.

21. Padel R. In and out of the mind: Greek images of the tragic self. Princeton, New Jersey: Princeton University Press, 1992.

22. Padel R. Whom gods destroy: elements of Greek and tragic madness. Princeton, New Jersey: Princeton University Press, 1995.

23. Foucault M. The hermeneutics of the subject: lectures at the Collège de France 1981-2. New York: Picador, 2005.

24. Tatum J. The mourner's song: war and remembrance from the lliad to Vietnam. Chicago: The University of Chicago Press, 2004:165 and note.

25. Macleod CW. Homer: Iliad, Book 24. Cambridge: Cambridge University Press, 1985:8-11.

26. Schein SL. The mortal hero. Berkeley: University of California Press, 1984:168-95.

27. Hojat M, Gonnelle JS, Nasca TJ, et al. Physician empathy: definition, components, measurement, and relationship to gender and specialty. Am J Psych 2002;159:1563-9.

28. Hojat M, Gonnella JS, Mangione S, et al. Empathy in medical students as related to academic performance, clinical competence and gender. Med Educ 2002;36:522-7

29. Hojat M, Mangione S, Nasca TJ, et al. An empirical study of decline in empathy in medical school. Med Educ 2004;38:934-41.

30. Onians RB. The origins of European thought. Cambridge: Cambridge University Press, 1988:23-89.

31. Wilmer HA. The doctor-patient relationship and issues of pity, sympathy and empathy. Br J Med Psychol 1968;41:243-8.

\section{Correction}

There was an error in the title of an article published in the December 2008 issue of the journal (Elliott C. The Best of the Belleville Literary Review. J Med Ethics; Medical Humanities 2008;34:117). The correct title of the book should be "The Best of the Bellevue Literary Review".

J Med Ethics; Medical Humanities 2009;35:12. doi:10.1136/jmh.2008.000661corr1 